\title{
ANALYSIS OF MANAGEMENT OF PRODUCTION POTENTIAL OF MACHINE-BUILDING ENTERPRISES OF KHARKIV REGION
}

\author{
Vladyslav Yakovlev' ${ }^{1}$, Olena Druhova ${ }^{2}$
}

\begin{abstract}
The purpose of the article is to study the management of production potential of machine-building enterprises in the Kharkiv region, 9 enterprises were analyzed and their production indicators were studied. The effectiveness of the production potential is characterized by production, technological, financial and innovative components. It should be noted that since the production potential is a component of the economic potential of the enterprise, the structure presented in Figure 1 is quite conditional. If we consider the production potential from this point of view, then, for example, its innovative component is inextricably linked with the innovative potential, and the financial component - with the financial potential. Sustainable development and competitiveness of an industrial enterprise depends on the level of production potential, which is the foundation of production activity. The production potential of an industrial enterprise is a complex, dynamic and stochastic system consisting of a number of interconnected components. At the legislative level, an attempt has been made to build a single model of an integrated indicator of the financial condition of large, medium and small enterprises. According to the approved IFI Procedure for assessing the financial condition of a potential beneficiary of an investment project, the level of financial condition of the enterprise is determined depending on the value of the integrated indicator, which allows the classification of enterprises in the industry or region. At the same time, questions about the structure of innovation potential remain controversial in the scientific literature. The development of an integrated module for the assessment of production potential is the first stage of the presented methodological approach. The next step is to improve the information subsystem of monitoring the financial and economic activity of industrial enterprises, which in turn is an integral part of the IT system of enterprise management. At this stage, it is necessary to develop software that provides analysis and comprehensive assessment of production capacity. After integrating the software module with IS monitoring, we have to test the software using the collected database on the financial and economic activity of the enterprise. Comparing the results of the assessment with the assessment from the analytical reports of independent experts will allow to determine the level of adequacy of the presented model and software. Methodology. The analysis was conducted on the basis of financial statements of enterprises of the machine-building industry of Kharkiv region for the period 2018, 2019, 2020. Results of the study show that the enterprises of the machine-building industry have low indicators of production potential, so enterprises need to change the strategy in the market to improve production capacity to increase competitiveness and improve. Practical implications. Given that companies have lost traditional markets in recent years and products are not in high demand in European markets, it is necessary to develop ways to improve the management of the potential of machine-building enterprises, seek new markets and strengthen cooperation with international companies. Value/originality. The study will help the management of enterprises to more effectively manage the enterprise and improve their production capacity.
\end{abstract}

Key words: indicator, enterprise, competitiveness, efficiency, management, production potential, capacity, market.

JEL Classification: D20, D24, O32

\footnotetext{
Corresponding author:

${ }^{1}$ National Technical University "Kharkiv Polytechnic Institute", Ukraine.

E-mail: vladyakovlev62@gmail.com

ORCID: https://orcid.org/0000-0003-4331-5101

${ }^{2}$ National Technical University "Kharkiv Polytechnic Institute", Ukraine.

E-mail: drugova.elena.sergeevna@gmail.com

ORCID: https://orcid.org/0000-0002-2404-1910
}

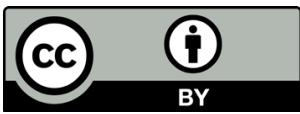

This is an Open Access article, distributed under the terms of the Creative Commons Attribution CC BY 4.0 


\section{Introduction}

In modern economic conditions in the world and in Ukraine questions of efficiency of production at machine-building enterprises, optimization of their activity and preservation of competitive advantages in the market acquire special value. Production potential has undergone profound changes through the development of new technological solutions, modernization and innovation. The task of competition in the field of increasing production capacity and finding new markets has shifted to the areas of IT, marketing and non-manufacturing activities. However, the role of the productive aspect cannot be underestimated. Production is the basis of industrial enterprises, and therefore requires the search for new, targeted and specific solutions to increase its potential, taking into account the requirements and wishes of consumers to gain a lasting competitive advantage in the market in the long run. As noted by the author in work (Yakovlev, 2018), the production potential is a system of components that provides the production of competitive products based on the resources of the enterprise to strengthen market positions and consumer needs. Due to technological changes and innovative development in production, it is important to understand the company's potential as a feature of practical and effective performance of production operations and the maximum use of technological possibilities. Without knowledge of the production potential, it is impossible to strategically develop and plan other activities of the enterprise, because the nature of production processes determines the relative role of the living labor force, facilities, equipment, financial resources and raw materials in creating opportunities for the enterprise to develop. The study of the potential in theoretical and practical terms is primarily determined by its role in the reproduction of the country's economy, in the reproduction of a socially oriented economy. Fuller use of the potential is the key task of the intensification of the country's economy and its enterprises (Haievska, 2011). Largescale investment projects and the introduction of new innovative processes have a positive impact on the dynamics of the company's potential growth. The company's potential is a complex and dynamic system. This agglomeration is characterized by certain patterns of development, the ability to be used, which largely depends on the efficiency of the economy, the pace and quality of its growth (Haiduchynskyi, Lupenko, Balytska, 2014).

The main task of the production potential of each enterprise is to create products with minimum resource costs, and the company must constantly search for new reserves in order to update production capacity and adapt it to the conditions of uncertainty (Zhuk, 2014).

\section{Research to assess the production potential}

Since it is assumed that the company has a management information system, it is essential to use a database that contains the necessary information about production processes. In addition, it makes sense to find additional sources that will provide the existing database with information needed to analyze and assess the production potential of the enterprise (Figure 1).

For a substantial assessment of production potential, it is necessary to form a set of indicators in accordance with the created criteria, which fully reflect the contribution of each component of production process. The analysis of scientific researches made possible to formulate the following criteria for selection of indicators:

- reaching the target numbers;

- availability of information needed to calculate the indicator;

- presence of clearly defined limit ranges or critical values;

- lack of a pronounced correlation with other selected indicators;

- comprehensibility;

- reliability and independence;

- spatial and temporal invariance;

- completeness of presentation and minimization;

- minimization of the number of indicators.

Based on the structure of production potential (Figure 1), the author proposes a system of quantitative indicators with subsequent selection of the most significant ones and aggregation of indicators according to the selected criteria. Initially, eighteen indicators, which characterise the production potential of the industrial enterprise, are selected. Adhering to the criteria of accessibility, minimization, lack of correlations, a number of indicators, which either did not affect the result of the integrated assessment, or there were difficulties in obtaining the information needed for calculation, are excluded from the set.

As a result of the previous research, the author offers to estimate the innovation potential of machinebuilding enterprise (IPME) with use of twelve indicators which quantitatively characterize components of potential (Table 1).

Table 3 shows the results of indicators calculation for ten industrial enterprises of Kharkiv region in 2020. Indicators calculation for the year 2018-2020 is presented in annex A.

After forming a set of indicators that meet the criteria, it is necessary to standardise them, making them dimensionless indicators. The choice of measurement scale must be justified, and under certain conditions, several scales can be used to check their impact on the outcome of the monitoring study. 


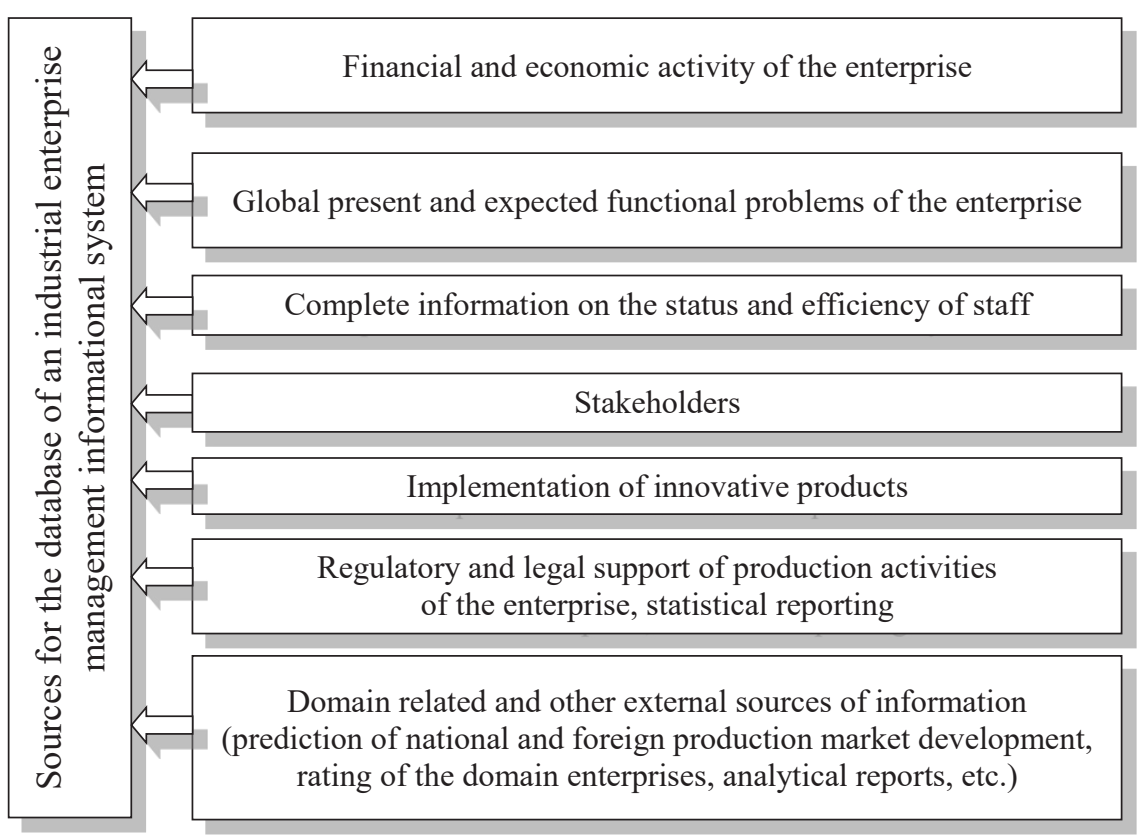

Figure 1. Information sources for databases

Table 1

Assessment indicators of the production potential of an industrial enterprise

\begin{tabular}{|c|c|c|}
\hline $\begin{array}{l}\text { № } \\
\mathrm{i} / \mathrm{e}\end{array}$ & Quantity indicator & Calculation formula \\
\hline $\mathrm{I}_{1}$ & Salary of production staff & $\begin{array}{l}\qquad \mathrm{I}_{1}=\mathrm{PCP} / \mathrm{WPS} \\
\text { where } \mathrm{PCP}-\text { production cost for the period; WPS - wages of production staff }\end{array}$ \\
\hline $\mathrm{I}_{2}$ & Work efficiency of production staff & $\begin{array}{l}\qquad \mathrm{I}_{2}=\mathrm{PCP} / \mathrm{ANS} \\
\text { where } \mathrm{PCP} \text { - production cost for the period; ANS - average number of production staff }\end{array}$ \\
\hline $\mathrm{I}_{3}$ & $\begin{array}{l}\text { Operational profitability } \\
\text { of production }\end{array}$ & $\begin{array}{l}\qquad \mathrm{I}_{3}=\mathrm{FROA} / \mathrm{PCP} \\
\text { where FROA }- \text { financial result from operating activities; } \mathrm{PCP}-\text { production cost for the period }\end{array}$ \\
\hline $\mathrm{I}_{4}$ & Turnover ratio of inventories & $\begin{array}{l}\qquad \mathrm{I}_{4}=\text { CGSP } / \text { AGP } \\
\text { where CGSP }- \text { cost of goods sold for the period; AGP }- \text { average goods price }\end{array}$ \\
\hline $\mathrm{I}_{5}$ & Return on capital of fixed assets & $\begin{array}{l}\qquad \mathrm{I}_{5}=\mathrm{PCP} / \mathrm{APFA} \\
\text { where } \mathrm{PCP}-\text { production cost for the period; APFA - average price of fixed assets }\end{array}$ \\
\hline $\mathrm{I}_{6}$ & $\begin{array}{l}\text { Coefficient of suitability } \\
\text { of fixed assets }\end{array}$ & $\begin{array}{l}\mathrm{I}_{6}=\text { SDFA } / \text { IPFA } \\
\text { where IPFA - initial price of fixed assets; SDFA - sum of depreciation of fixed assets }\end{array}$ \\
\hline $\mathrm{I}_{7}$ & Coefficient of renewal of fixed assets & $\begin{array}{c}\mathrm{I}_{7}=\mathrm{PFAO} / \mathrm{IPFAE} \\
\text { where IPFAE - initial price of fixed assets in the end of report period; } \\
\text { PFAO - price of the fixed assets put into operation }\end{array}$ \\
\hline $\mathrm{I}_{8}$ & Used material efficiency & $\begin{array}{c}\qquad \mathrm{I}_{8}=\mathrm{PCP} / \mathrm{SC} \\
\text { where } \mathrm{PCP}-\text { production cost for the period; } \mathrm{SC}-\text { sum of all costs }\end{array}$ \\
\hline
\end{tabular}

Source: author's own workings

\section{Analysis of the production potential of machine-building enterprises}

Table 2

Assessment indicators of the production potential of an industrial enterprise in 2020

\begin{tabular}{|c|l|c|c|c|c|c|}
\hline № & \multicolumn{1}{|c|}{ Indicator } & № 1 & № 2 & № 3 & № 4 & № 5 \\
\hline $\mathrm{I}_{1}$ & Salary of production staff & 9,68 & 3,14 & 2,55 & 2,92 & 8,71 \\
\hline $\mathrm{I}_{2}$ & Work efficiency of production staff & 2013,98 & 473,03 & 267,09 & 594,08 & 1725,78 \\
\hline $\mathrm{I}_{3}$ & Operational profitability of production & 0,1094 & $-0,1078$ & $-0,6510$ & 0,0626 & 0,0903 \\
\hline $\mathrm{I}_{4}$ & Turnover ratio of inventories & 9,12 & 2,44 & 1,50 & 0,80 & 4,60 \\
\hline $\mathrm{I}_{5}$ & Return on capital of fixed assets & 2,64 & 0,49 & 0,18 & 0,65 & 2,25 \\
\hline $\mathrm{I}_{6}$ & Coefficient of suitability of fixed assets & 0,44 & 0,76 & 0,41 & 0,18 & 0,76 \\
\hline $\mathrm{I}_{7}$ & loefficient of renewal of fixed assets & 0,01 & 0,06 & 0,00 & 0,00 & 0,06 \\
\hline $\mathrm{I}_{8}$ & Used material efficiency & 2,30 & 1,40 & 1,55 & 3,17 & 1,09 \\
\hline
\end{tabular}


Table 3

Assessment indicators of the production potential of an industrial enterprise in 2020 (Part 2)

\begin{tabular}{|c|l|c|c|c|}
\hline № & \multicolumn{1}{|c|}{ Indicator } & № 6 & № 7 & № 8 \\
\hline $\mathrm{I}_{1}$ & Salary of production staff & 3,21 & 3,19 & 4,04 \\
\hline $\mathrm{I}_{2}$ & Work efficiency of production staff & 367,79 & 742,18 & 984,57 \\
\hline $\mathrm{I}_{3}$ & Operational profitability of production & 0,0834 & 0,0584 & 0,1778 \\
\hline $\mathrm{I}_{4}$ & Turnover ratio of inventories & 10,14 & 4,59 & 12,68 \\
\hline $\mathrm{I}_{5}$ & Return on capital of fixed assets & 8,46 & 4,76 & 0,0057 \\
\hline $\mathrm{I}_{6}$ & Coefficient of suitability of fixed assets & 0,22 & 0,48 & 0,53 \\
\hline $\mathrm{I}_{7}$ & Coefficient of renewal of fixed assets & 0,01 & 0,01 & 0,65 \\
\hline $\mathrm{I}_{8}$ & Used material efficiency & 1,39 & 2,56 & 0,04 \\
\hline
\end{tabular}

№ 1 - PC "Frunze plant"; № 2 - PC "Kharkiv Tractor Plant"; № 3 - PC "KhPZ"; №4 - PC "Turboatom"; № 5 - PC Plant "Pivdenkabel"; № 6 - PC "Elektromashine"; № 7 - PC Kharkiv machine-building plant "Svitlo Shakhtar"; № 8 - PC "Kharkiv tile factory"; № 9 - PC "KhKMZ"

Source: author's own workings

Before building the model of integrated assessment, let us conduct a comparative analysis of indicators that characterise the production potential of nine industrial enterprises in the Kharkiv region. Figure 2 shows the indicators of operating profitability of enterprises in 2018-2020. The leader among the surveyed enterprises of the Kharkiv region is PC "Turboatom". At the same time, in three years the profitability of production has decreased tenfold. PC "KhPZ" is unprofitable in 2019-2020.

PC "Kharkiv Tractor Plant" and PC "Svitlo Shakhtar" also recorded losses in 2019 and 2020. Also, the following companies had positive growth rates of the indicator: PC "Kharkiv tile factory" (48\%), PC "Elektromashine" (39\%), PC "Svitlo Shakhtar" (17\%), PC "Frunze plant" (9\%).

Table 4 shows production staff efficiency for costs in 2018-2020. During the assessed period, the efficiency decreased for all surveyed enterprises except for PC "KhKMZ". The largest rate of decline was recorded in PC "KhPZ". At the end of 2020, PC "Pivdenkabel" and "Frunze plant" exceeded 8 points. The lowest figure of 2.55 was recorded in PC "KhPZ".

PC "Elektromashin" has the highest indicators of fixed assets capital efficiency, PC "Kharkiv Tractor Plant" has the lowest indicators in 2018-2020 (Figure 3). Almost all enterprises have a decrease in the indicators in three years period, the largest rates of decline (more than 200\%) were recorded in PC "Kharkiv Tractor Plant" and PC "KhKMZ".

Figure 2 shows the indicators of material recovery of production. We can see growth of the indicator for 7 production enterprises, with the highest growth rates and indicator level in OC "Turboatom". PC "KhKMZ" has the lowest rate, with of decline of $46 \%$ over three years.

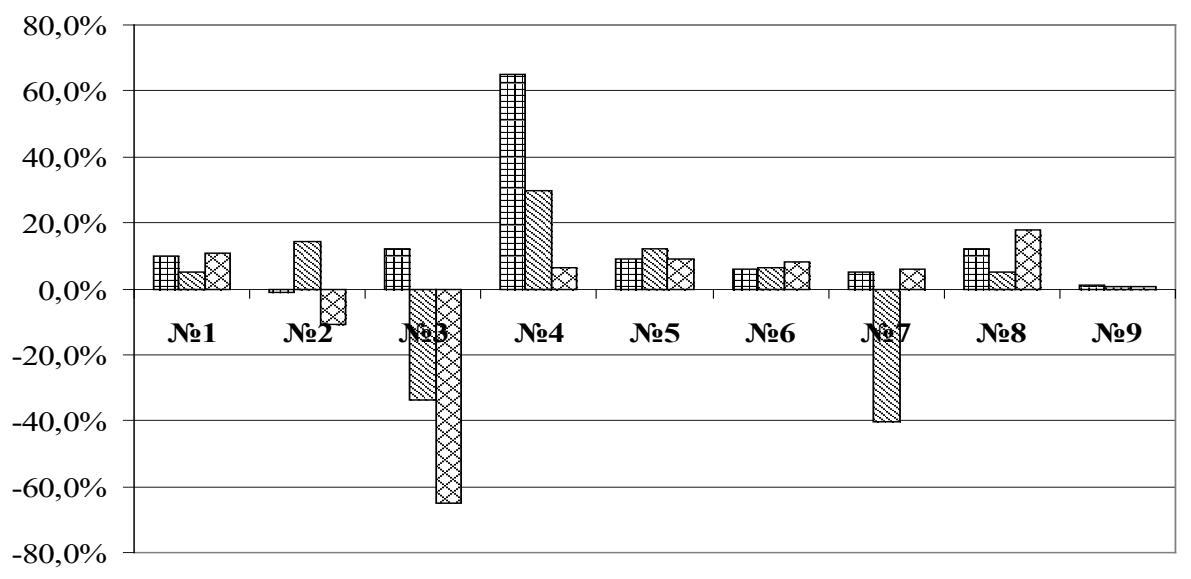

四 20182019 目 2020

Figure 2. Dynamic of operating profitability of production enterprise

№ 1 - PC "Frunze plant"; № 2 - PC "Kharkiv Tractor Plant"; № 3 - PC "KhPZ"; № 4 - PC "Turboatom"; № 5 - PC Plant "Pivdenkabel"; № 6 - PC "Elektromashine"; № 7 - PC Kharkiv machine-building plant "Svitlo Shakhtar"; № 8 - PC "Kharkiv tile factory"; № 9 - PC "KhKMZ"

Source: author's own workings 
Table 4

Salaries of production staff of surveyed enterprises

\begin{tabular}{|c|l|c|c|c|c|}
\hline № & \multicolumn{1}{|c|}{ Enterprise } & 2018 & 2019 & 2020 & Rate of decrease, $\%$ \\
\hline 1 & PC "Frunze plant" & 13,69 & 11,95 & 9,68 & 41,4 \\
\hline 2 & PC "Kharkiv Tractor Plant" & 4,56 & 4,51 & 3,14 & 45,2 \\
\hline 3 & PC "KhPZ" & 5,12 & 3,22 & 2,55 & 100,8 \\
\hline 4 & PC "Turboatom" & 3,41 & 3,62 & 2,92 & 16,8 \\
\hline 5 & PC "Pivdenkabel" & 14,89 & 12,2 & 8,71 & 71,0 \\
\hline 6 & PC "Elektromashin" & 4,58 & 4,86 & 3,21 & 42,7 \\
\hline 7 & PC "Svitlo Shakhtar" & 3,25 & 3,12 & 3,19 & 1,9 \\
\hline 8 & PC "Kharkiv tile factory" & 6,4 & 5,48 & 4,04 & 58,4 \\
\hline 9 & PC "KhKMZ" (Kharkiv Boiler and Mechanical Plant) & 2,73 & 1,59 & 3,27 & $-16,5$ \\
\hline
\end{tabular}

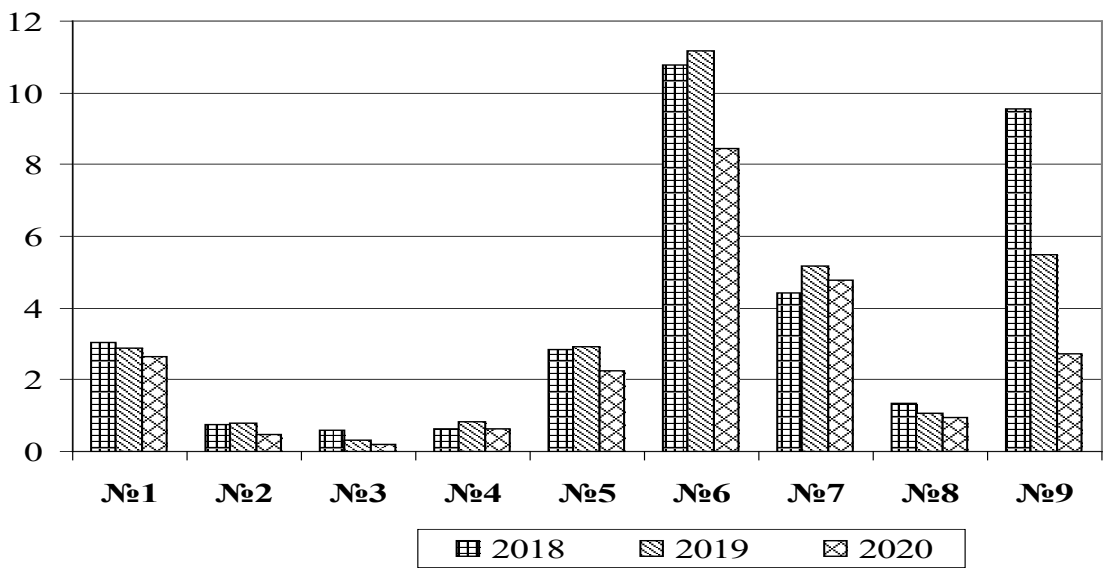

Figure 3. Return on fixed assets in 2018-2020

* № 1 - PC "Frunze plant"; № 2 - PC "Kharkiv Tractor Plant"; № 3 - PC "KhPZ"; № 4 - PC "Turboatom"; № 5 - PC "Pivdenkabel"; № 6 - PC "Elektromashin"; № 7 - PC Kharkiv machine-building plant "Svitlo Shakhtar"; № 8 - PC "Kharkiv tile factory"; № 9 - PC "KhKMZ". Source: authors own workings

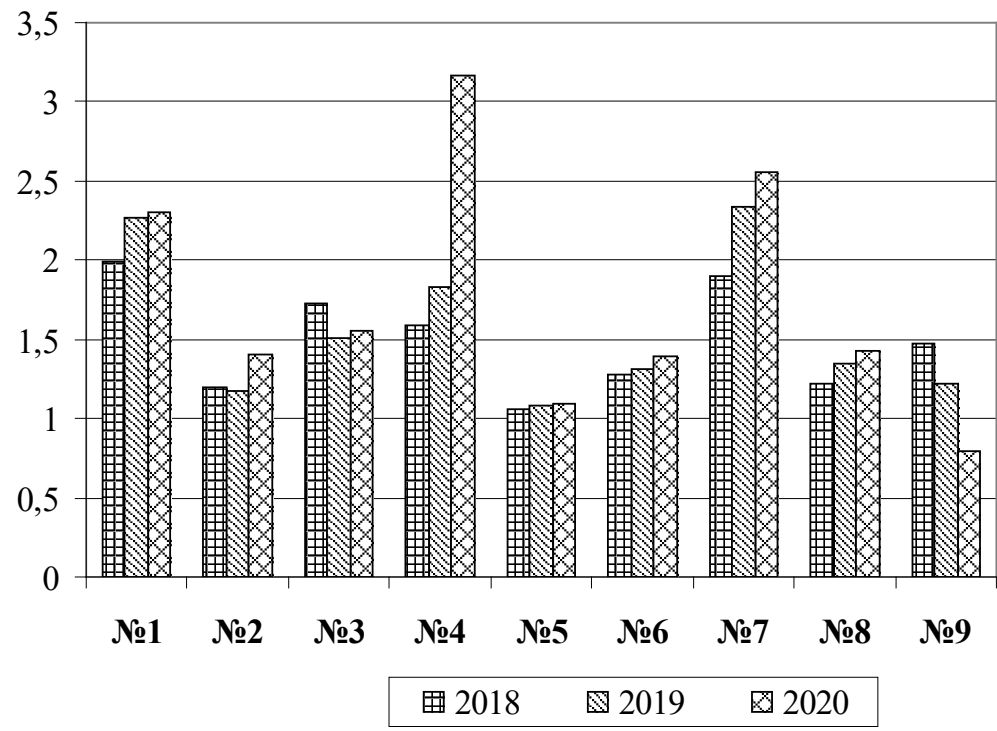

Figure 4. Material efficiency of production in 2018-2020

* № 1 -PC "Frunze plant"; № 2 - PC "Kharkiv Tractor Plant"; № 3 - PC "KhPZ"; №4 - PC "Turboatom"; № 5 - PC "Pivdenkabel"; № 6 - PC "Elektromashin"; № 7 - PC Kharkiv machine-building plant "Svitlo Shakhtar"; № 8 - PC "Kharkiv tile factory"; № 9 - PC "KhKMZ".

Source: author's own workings 
Thus, based on the analysis, we can indicate the position of each company for individual indicators that characterize the production potential.

The main requirement for indicators is dimensionlessness and having a single scale of measurement. The following formulas for calculating dimensionless indicators used in [1]:

$$
\text { 1. } x_{k}=\frac{\mathrm{I}_{\mathrm{k}}-\mathrm{I}_{\mathrm{k}}^{\min }}{\mathrm{I}_{\mathrm{k}}{ }^{\max }-\mathrm{I}_{\mathrm{k}}^{\min }} \text {, }
$$

If the indicator Iк corresponds to the highest value (straight connection);

$$
x_{k}=\frac{\mathrm{I}_{\mathrm{k}}{ }^{\max }-\mathrm{I}_{\mathrm{k}}}{\mathrm{I}_{\mathrm{k}}{ }^{\text {max }}-\mathrm{I}_{\mathrm{k}}{ }^{\text {min }}},
$$

If the indicator IK corresponds to the lowest value (opposite connection). Here $\mathrm{I}_{\mathrm{k}}^{\min }$ and $\mathrm{I}_{\mathrm{k}}^{\max }-$ minimal and maximal indicator values.

$$
\text { 2. } x_{k}=\frac{\mathrm{I}_{\mathrm{k}}-\overline{\mathrm{I}}_{\mathrm{k}}}{\sigma_{\mathrm{k}}} \text {, }
$$

where $\overline{\mathrm{I}}_{\mathrm{k}}$ - average indicator value, $\sigma_{k}$ - average square deviation of $\mathrm{k}$-value.

$$
\text { 3. } x_{k}=1-\frac{\left|\mathrm{I}_{\mathrm{k}}-\mathrm{I}_{\mathrm{kj}}^{\mathrm{opt}}\right|}{\max \left\{\left(\mathrm{I}_{\mathrm{k}}^{\mathrm{opt}}-\mathrm{I}_{\mathrm{kj}}^{\mathrm{min}}\right),\left(\mathrm{I}_{k}^{\mathrm{max}}-\mathrm{I}_{\mathrm{kj}}^{\mathrm{opt}}\right)\right\}} \text {, }
$$

where $I_{\mathrm{kj}}^{\mathrm{opt}}$ - optimal (normative) indicator value.

The development of economic and mathematical model for integrated assessment of an enterprise production potential must begin with the study of various methods for processing multidimensional statistical information. The main criterion for such a method would be the availability of appropriate software and accessibility of results interpretation for an average person. Studies have shown that the methods of principal components, cluster, discriminant, factor, and taxonomic analysis prove to be optimal for solving most problems.

The method of taxonomic analysis is characterised by the simplicity of the mathematical apparatus and calculation program, as well as the absence of any special requirements for the set of studied objects. The other methods listed above are implemented in the "Statistica" programs.

The paper proposes to use the methods of the main components of taxonomic analysis, which will help to confirm the reliability and adequacy of the selected model for integrated assessment of production potential. Integrated evaluation allows for determining the position of each industrial enterprise in an industry or separate region.

\section{Conclusions}

The advantage of the proposed approach to the integrated assessment of the level of production potential is the ability to use software for multidimensional statistical analysis, among which is the software package STATISTICA.

Development of an integrated assessment module of production potential is the first stage of the presented methodological approach. The next stage is to improve the information subsystem for monitoring the financial and economic activities of industrial enterprises, which in turn is an integral part of the information system of enterprise management. At this point, it is necessary to develop software that provides analysis and comprehensive assessment of production capacity. After the integration of the software module in the IS monitoring, we need to test the software using the accumulated database of financial and economic activities of an enterprise. Comparing the evaluation results with the rating from analytical reports of independent experts will allow us to establish the level of adequacy of the presented model and software.

After confirming the adequacy of the selected assessment model, it is necessary to organize a process of continuous analysis of the state and change of production capacity, which will automate the process of forming operational and final analytical reports.

The results of the integrated assessment allow us to obtain a rating of the studied industrial enterprises according to the following ranking scale:

1) high level - the values of the integral index are in the range of $[0,7-1,0]$;

2) sufficient level - the values of the integral index are are in the range of $(0.3-0.7)$;

3 ) low level - the values of the integral index are in the range of $[0,1-0,3)$;

4) critical level - the values of the integral index are in the range of $[0-0,1)$.

\section{References:}

Haievska, L. M., \& Chernova, O. V. (2011). Vyrobnychyi potentsial - osnova rozvytku pidpryiemstva [Production potential is the basis of enterprise development]. Visnyk ZHDTU, 1(55), 184. (in Ukrainian)

Haiduchynskyi, P. I., Lupenko, Yu. O., Balytska, V. V., and other (2003). Rozvytok pidpryiemstva v Ukraini [Enterprise development in Ukraine]. Kyiv: Noradruk. (in Ukrainian)

Zhuk, O. E. (2014). Vyrobnychyi potentsial yak faktor rozvytku pidpryiemstva za umov nevyznachenosti [Production potential as a factor of enterprise development under conditions of uncertainty]. Visnik Hmelnickogo nacionalnogo universitetu, 3, 207. (in Ukrainian)

Yakovlev, V. I. (2018). Traktuvannia ekonomichnoi katehorii vyrobnychoho potentsialu [Interpretation of the economic category of production potential]. Prichornomorski ekonomichni studii, 34, 115-120. (in Ukrainian) 